\title{
ANALISA KINERJA SISTEM HEATING DEHUMIDIFIER MENGGUNAKAN AC SPLIT UNTUK PENGERINGAN IKAN
}

\author{
Yudhy Kurniawan ${ }^{1}$, Ruslani $^{2}$, Fadil Akbar Anggriawan ${ }^{3}$ \\ 1,2,3 Teknik Pendingin dan Tata Udara Politeknik Negeri Indramayu \\ Jl. Raya Lohbener Lama No. 08 Indramayu 45252 \\ E-mail : k.yudhy@yahoo.com ${ }^{1}$, ruslanialfatih26@gmail.com², fadilakbaranggriawan@yahoo.co.id ${ }^{3}$
}

\begin{abstract}
Abstrak
Salah satu daerah potensial besar dalam sektor perikanan di Provinsi Jawa Barat adalah Kabupaten Indramayu. Prosentase produksi perikanan Indramayu yang menyumbang $60 \%$ dari kebutuhan perikanan. Masyarakat Indramayu, khususnya daerah pesisir pantai utara kabupaten Indramayu sangat bergantung pencahariannya pada sektor ini. Selama ini dalam proses produksi ikan kering masih mengandalkan kondisi alam panas matahari. Ketika datang musim hujan pemilik pengolahan ikan rugi, karena pengeringan alami terhambat dan akhirnya pesanan dan pelanggan terabaikan akibat kualitas ikan menurun dan harga penjualan melambung dua kali lipat. Karenanya perlu adanya perhatian dalam meningkatkan kualitas produksi pengolahan ikan kering, yaitu salah satunya dengan memanfaatkan AC split sebagai heating dehumidifier (penurun kelembaban panas) untuk pengeringan ikan. Peralatan ini dimodifikasi dengan memanfaatkan panas buang dari condenser sebagai reheat kemudian ditambahkan dengan heater electric yang dikontrol sesuai kebutuhan pengeringan, dan setelah itu dihembuskan dengan bantuan fan/blower ke ruang pengering yang berisi ikan pada rak-rak yang tersusun. Pada penelitian ini, variabel proses yang divariasikan adalah temperatur dan kelembaban relative $(\mathrm{RH})$. Dari analisis yang dilakukan, maka disimpulkan pada settingan menggunakan heater, dimana diperoleh nilai temperatur output $50{ }^{\circ} \mathrm{C}$, dan $\mathrm{RH}$ sebesar $32,1 \%$.
\end{abstract}

Kata Kunci : Heating dehumidifier, kinerja,temperatur, dan kelembaban relatif (RH)

\begin{abstract}
One of great potential area in the fisheries sector in West Java province is Indramayu District. Percentage of fisheries production which accounts for $60 \%$ of the needs of the fishery. Indramayu community, especially the northern coastal areas of Indramayu district of livelihood relies heavily on the this sector. During this process the dried fish production still relies on the natural conditions of the solar thermal. So that when the rainy season the fishermen feel a loss, because of natural heating hampered and finally ignored orders from customers due to the and declining fish quality, so prices soaring sales doubled. Hence, the need for attention to improving the quality of production of dry fish processing, is one of the way by utilizing the split Air Conditioning (AC) as a heating dehumidifier for drying fish. This equipment is modified by utilizing the waste heat from the condenser as reheat is then added to the electric heater is controlled according to the needs drying, and after that it was blown with using fan/blower to the drying chamber containing the fish on the shelves are arranged. The results obtained can be analyzed on the performance, drying temperatur and relative humidity $(R H)$ or water content is as expected.
\end{abstract}

Keywords : Heating dehumidifier, performance, temperatur, relative humidity $(\mathrm{RH})$

\section{PENDAHULUAN}

\section{I.1 Permasalahan Penelitian}

Kabupaten Indramayu merupakan daerah yang berada ditepi utara propinsi Jawa Barat. Letak geografis yang berada dekat pantai utara membentuk corak karakteristik mata pencaharian masyarakat setempat khususnya didaerah pesisir pantai utara banyak terdapat aktifitas pelelangan dan pengolahan ikan. Hasil tangkapan ikan laut tersebut bersifat musiman. Dalam arti suatu saat ikan yang didapat sangat melimpah, namun disaat yang lain sedikit. Sehingga tidak heran jika pada saat produk panen ikan melimpah, banyak ikan yang tidak dimanfaatkan atau dijual jika tidak ditangani akan menjadi busuk. Proses pembusukan berdampak buruk pada menurunnya kualitas mutu ikan dan akhirnya komoditas harga ikan menjadi rendah. Tentu akan sangat merugikan terutama bagi nelayan yang menjadikannya satu-satunya mata pencahariannya. Untuk mencegah proses pembusukan tersebut, perlu dikembangkan berbagai cara untuk menangani permasalahan tersebut, yang salah satu teknologinya adalah mengembangkan pengolahan ikan dengan proses pengering dehumidifikasi (penurunan kelembaban). Selama ini dari hasil survey dan interview langsung dengan nelayan yang menjadi mitra peneliti, 
proses pengeringan umumnya dilakukan secara konvensional, yaitu dengan memanfaatkan panas sinar matahari langsung. Kendalanya adalah jika sewaktuwaktu musim penghujan tiba, para nelayan tidak bisa lagi mengeringkan ikannya sehingga kualitas dan kuantitas penjualan menurun, dan otomatis harga ikan menjadi jatuh. Disamping itu ikan yang dijemur di alam terbuka membutuhkan waktu pengeringan hingga +/- 3 hari, membutuhkan area penjemuran yang luas, belum lagi dari sisi higienitas ikan yang berpotensi terkontaminasi oleh partikel debu yang kotor dan lalat. Teknologi pengeringan ikan dengan melibatkan proses dehumidifikasi bermaksud untuk membuang sebagian besar air yang terkandung pada ikan melalui penguapan air ke udara karena perbedaan kandungan uap air antara udara dengan bahan yang dikeringkan. Tujuan dari proses tersebut diharapkan mampu memperpanjang umur simpan bahan dengan cara penurunan kelembaban udara atau kadar air. Turunnya kelembaban udara air akan dapat menghambat pertumbuhan mikroba dan aktifitas yang disebabkan oleh enzim, karena suhu pemanasan tidak cukup tinggi untuk membunuh mikroba atau menonaktifkan enzim[1]. Selain itu tujuan lain dari proses pengeringan dehumidifikasi ini adalah untuk mengurangi volume dan berat ikan yang ditangani dengan biaya pengangkutan dan penyimpanan menurun. Pemanfaatan alat ini pula diharapkan mampu mempercepat proses pengeringan dan penurunan kelembaban dijaga sebesar 25\%-30\%, dimana pada umumnya kadar air ikan bervariasi antara 50-80\% yang pada kondisi tersebut bakteri dan enzim bekerja[2]. Proses pemanasan inipun tidak berdampak pada penurunan kualitas gizi ikan, asalkan temperatur pengeringan masih dibawah $85^{\circ} \mathrm{C}[3]$, khusus untuk pengeringan ikan, temperatur pengeringan yang dianjurkan adalah $40{ }^{\circ} \mathrm{C}-50{ }^{\circ} \mathrm{C}$ [4]. Perhatian peneliti terhadap kondisi para nelayan yang mata pencahariannya hanya bergantung pada penjualan ikan, ditunjang dengan kompetensi peneliti khususnya bidang teknik pendingin dan tata udara inilah, diharapkan memberi solusi besar terhadap permasalahan yang ada dimasyarakat dimana tidak jauh dari perguruan tinggi peneliti.

\section{I.2 Wawasan dan Rencana Pemecahan Masalah}

Berdasarkan latar belakang tersebut di atas, masalah yang akan diselesaikan dalam penelitian ini adalah sebagai berikut :

1. Bagaimana merancang dan membuat heatingdehumidifier menggunakan AC Split?

2. Bagaimana kinerja dari system heating dehumidifier menggunakan AC Split?

3. Apakah terjadi kenaikan temperatur dan penurunan kelembaban sesuai yang diharapkan setelah menggunakan sistem ini ?

\section{I.3 Rumusan Tujuan Penelitian}

Tujuan penelitian ini adalah mengetahui kinerja, temperatur pengeringan dan kelembaban relative $(\mathrm{RH})$ atau kadar air yang dihasilkan dari system heating dehumidifier menggunakan AC Split untuk pengeringan ikan

\section{I.4 Kajian Teoritik \\ Pengertian Pengeringan}

Pengeringan adalah proses pemindahan atau pengeluaran kandungan air bahan hingga mencapai kandungan air tertentu agar kecepatan kerusakan bahan dapat diperlambat. Proses pengeringan ini dipengaruhi oleh suhu, kelembaban udara lingkungan, kecepatan aliran udara pengering, kandungan air yang diinginkan, energi pengering, dan kapasitas pengering. Pengeringan yang terlampau cepat dapat merusak bahan, oleh karena permukaan bahan terlalu cepat kering sehingga kurang bisa diimbangi dengan kecepatan gerakan air bahan menuju permukaan. Karenanya menyebabkan pengerasan pada permukaan bahan selanjutnya air dalam bahan tidak dapat lagi menguap karena terhambat. Disamping itu, operasional pengeringan dengan suhu yang terlalu tinggi dapat merusak bahan. Pengaturan suhu dan lamanya waktu pengeringan dilakukan dengan memperhatikan kontak antara alat pengering dengan alat pemanas (baik itu berupa udara panas yang dialirkan maupun alat pemanas lainnya). Namun demi pertimbanganpertimbangan standar gizi maka pemanasan dianjurkan tidak lebih dari $85^{\circ} \mathrm{C}$.

Pengeringan ikan adalah pengawetan dengan cara penguapan air dari ikan, sehingga tercipta suasana yang tidak memungkinkan bakteri pembusuk dan jamur untuk tumbuh dan kegiatan enzymatic.

Batas kadar air ikan secara umum yang diperlukan $30 \%$ sampai $40 \%$, supaya perkembangan jasad - jasad bakteri pembusuk dan jamur dapat terhenti.

\section{Prinsip Pengeringan}

Proses pengeringan pada prinsipnya adalah proses mengurangi kadar air dalam ikan. Menurut Abdullah (2003), untuk mencegah bakteri dan enzyme bekerja dalam ikan, selain mengurangi kadar air dalam ikan, diperlukan juga pengendalian temperatur dan $\mathrm{RH}$ udara tempat penyimpanan ikan. Beberapa variabel yang penting dalam proses pengeringan ikan adalah: temperatur, $\mathrm{RH}$ dan laju aliran udara serta waktu pengeringan. Kadar air ikan bervariasi antara 50\% - 80\%. Untuk mengurangi aktivitas bakteri dan enzym, kadar air ikan sebaiknya dijaga dibawah $25 \%$.

Menurut Murniyati dan Sunarman (2000), cara yang umum untuk mengeringkan ikan adalah dengan menguapkan air dari tubuh ikan, yaitu dengan menggunakan tiupan udara panas. Penguapan dimulai dari bagian permukaan, kemudian menjalar ke bagian - bagian yang lebih dalam. Kecepatan penguapan atau pengeringan ditentukan oleh faktor seperti Kecepatan Udara, Temperatur Udara, Kelembapan Udara,Ukuran dan Tebal Ikan, Arah Aliran Udara Terhadap Ikan, Sifat Ikan.

\section{Dehumidifier}

Yaitu sebuah alat yang berfungsi untuk mengurangi kandungan uap air dalam suatu ruangan, sehingga kadar kelembaban menjadi rendah dengan melalui proses yang dinamakan dehumidifikasi. Dehumdifikasi sendiri yaitu merupakan proses pengurangan kadar air didalam udara. Dehumidifier juga berasal dari kata dehumidify artinya 
mengurangi kelembaban. Kelembaban adalah banyak uap air yang terkandung dalam udara.

Adapun alat yang akan digunakan untuk proses penelitian ini menggunakan jenis Refrigerant dehumidifier adalah yang sering digunakan, karena dapat dengan mudah dioperasikan dan efektif dalam sebagian besar aplikasi domestik maupun komersial. Refrigerant dehumidifier sangat cocok digunakan pada lingkungan yang bertemperatur hangat dengan kadar kelembaban relatif udara yang cukup rendah.

Cara kerja dari jenis dehumidifier ini sangat tergantung pada proses refrigerasi kompresi uap, karena memanfaatkan evaporator dan kondensor. Dimana udara yang masuk dialirkan melewati evaporator terlebih dahulu untuk menghasilkan udara dingin dengan kandungan uap air yang cenderung tinggi kemudian udara tersebut dialirkan kembali menuju kondensor. Fungsi dari kondensor dalam proses dehumidifikasi ini yaitu untuk menyerap kandungan uap air udara yang sebelumnya melewati evaporator sehingga udara yang dihasilkan cenderung hangat dan kering.

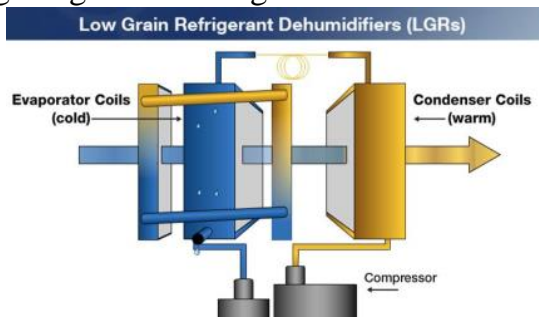

Gambar 1.1 Proses Refrigerant Dehumidifier[5]

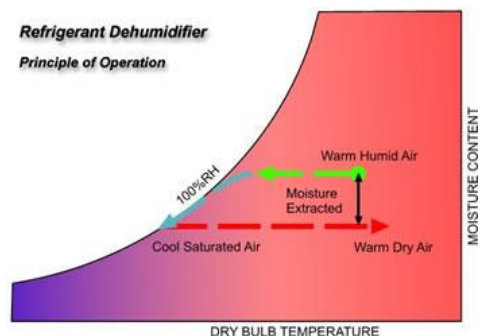

Gambar 1.2 Proses Refrigerant Dehumidifier Pada Diagram Psikrometrik [6]

\section{Sistem Kompresi Uap pada AC Split}

Sistem kompresi uap merupakan dasar sistem refrigerasi yang terbanyak digunakan, dengan komponen utamanya adalah kompresor, evaporator, alat ekspansi (Throttling Device), dan kondensor. Keempat komponen tersebut melakukan proses yang saling berhubungan dan membentuk siklus refrigerasi kompresi uap. Pada sistem ini juga terdapat refrigeran atau fluida yang digunakan sebagai media penyerap panas dari kabin atau ruangan yang dikondisikan ke dalam sistem, kemudian dihantarkan dan membuang panas tersebut ke lingkungan. Pada AC split yang digunakan untuk pemanas dehumidifier menggunakan system kompresi uap.

Sistem yang terjadi pada sistem refrigerasi kompresi uap merupakan sistem tertutup, adapun siklus yang terjadi terlihat pada Gambar 1.3 di bawah ini.

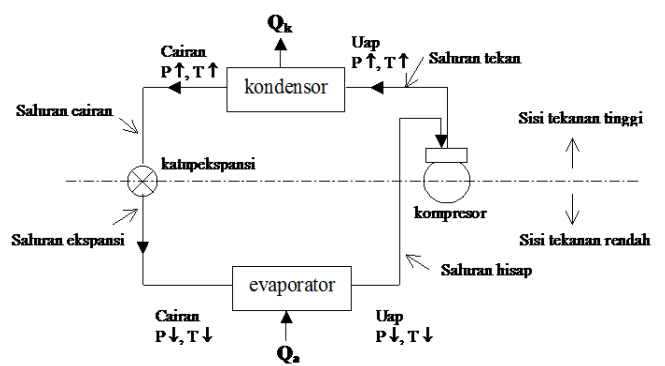

Gambar 1.3 Siklus Sistem Refrigerasi Kompresi Uap [8]

Pada diagram P-h, siklus refrigerasi kompresi uap dapat digambarkan sebagai berikut :

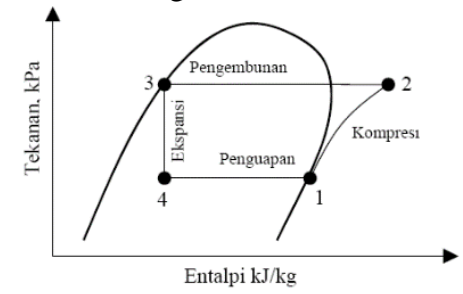

Gambar 1.4 Siklus Sistem Refrigerasi Pada Diagram P-h

1) Kompresi

Proses ini berlangsung di kompresor secara isentropik adiabatik. Kondisi awal refrigeran pada saat masuk di kompresor adalah uap jenuh bertekanan rendah, setelah dikompresi refrigeran menjadi uap bertekanan tinggi. Besarnya kerja kompresi per satuan massa refrigeran bisa dihitung dengan rumus:

$$
\mathrm{q}_{\mathrm{w}}=\mathrm{h}_{2}-\mathrm{h}_{1}
$$

Besarnya daya kerja kompresi yang dilakukan:

$$
\mathrm{Q}_{\mathrm{w}}=\dot{\mathrm{m}} \times \mathrm{q}_{\mathrm{w}} \text {. }
$$

dimana,

$\mathrm{Q}_{\mathrm{w}} \quad=$ Daya kompresi yang dilakukan $(\mathrm{kW})$

$\dot{\mathrm{m}} \quad=$ Laju aliran massa refrigeran $(\mathrm{kg} / \mathrm{s})$

$\mathrm{q}_{\mathrm{w}}=$ kerja kompresi yang dilakukan $(\mathrm{kJ} / \mathrm{kg})$

$\mathrm{h}_{2} \quad=$ entalpi refrigeran masuk kompresor $(\mathrm{kJ} / \mathrm{kg})$

$\mathrm{h}_{1} \quad=$ entalpi refrigeran masuk kompresor $(\mathrm{kJ} / \mathrm{kg})$

2) Kondensasi

Proses ini berlangsung di kondensor. Refrigeran yang bertekanan dan bertemperatur tinggi keluaran dari kompresor membuang kalor sehingga fasanya berubah menjadi cair.

Besar panas per satuan massa refrigeran yang dilepaskan di kondensor dinyatakan sebagai :

$$
\mathrm{q}_{\mathrm{c}}=\mathrm{h}_{2}-\mathrm{h}_{3}
$$

Besarnya kapasitas kondensor yang dilakukan:

$$
\mathrm{Q}_{\mathrm{c}}=\dot{\mathrm{m}} \times \mathrm{q}_{\mathrm{c}}
$$

dimana,

$\mathrm{Q}_{\mathrm{c}} \quad=$ Kapasitas pembuangan panas $(\mathrm{kW})$

$\dot{\mathrm{m}} \quad=$ Laju aliran massa refrigeran $(\mathrm{kg} / \mathrm{s})$

$\mathrm{q}_{\mathrm{c}} \quad=$ kalor yang dilepas oleh kondensor $(\mathrm{kJ} / \mathrm{kg})$

$\mathrm{h}_{2} \quad=$ entalpi refrigeran masuk kondensor $(\mathrm{kJ} / \mathrm{kg})$

$\mathrm{h}_{3}=$ entalpi refrigeran keluar kondensor $(\mathrm{kJ} / \mathrm{kg})$

3) Ekspansi

Proses ini berlangsung secara isoentalpi, hal ini berarti tidak terjadi penambahan entalpi tetapi terjadi drop tekanan dan penurunan temperatur. Proses 
penurunan tekanan terjadi pada katup ekspansi yang berbentuk pipa kapiler atau orifice yang berfungsi mengatur laju aliran refrigeran dan menurunkan tekanan.

$$
\mathrm{h}_{3}=\mathrm{h}_{4} \text {. }
$$

dimana,

$\mathrm{h}_{3}=$ entalpi refrigeran saat masuk ekspansi $(\mathrm{kJ} / \mathrm{kg})$

$\mathrm{h}_{4}=$ entalpi refrigeran saat keluar ekspansi $(\mathrm{kJ} / \mathrm{kg})$

4) Evaporasi

Proses ini berlangsung di evaporator secara isobar isotermal. Refrigeran dalam wujud cair bertekanan rendah menyerap kalor dari lingkungan / media yang didinginkan sehingga wujudnya berubah menjadi gas bertekanan rendah.

Besarnya kalor yang diserap oleh evaporator adalah:

$$
\mathrm{q}_{\mathrm{e}}=\mathrm{h}_{1}-\mathrm{h}_{4}
$$

Besarnya kapasitas kondensor yang dilakukan:

dimana,

$$
\mathrm{Q}_{\mathrm{e}}=\dot{\mathrm{m}} \times \mathrm{q}_{\mathrm{e}}
$$

$\mathrm{Q}_{\mathrm{e}} \quad=$ Kapasitas pendinginan $(\mathrm{kW})$

$\dot{\mathrm{m}} \quad=$ Laju aliran massa refrigeran $(\mathrm{kg} / \mathrm{s})$

$\mathrm{q}_{\mathrm{e}} \quad=$ kalor yang diserap oleh evaporator $(\mathrm{kJ} / \mathrm{kg})$

$\mathrm{h}_{4} \quad=$ entalpi refrigeran masuk evaporator $(\mathrm{kJ} / \mathrm{kg})$

$\mathrm{h}_{2}=$ entalpi refrigeran keluar evaporator $(\mathrm{kJ} / \mathrm{kg})$

Koefisien Kinerja (COP) Pada Sistem Kompresi Uap modifikasi Sistem Heating Dehumidifier

Perbandingan antara besarnya kalor dari lingkungan yang dapat diambil oleh panas buang kondensor dengan kerja kompresor yang harus dilakukan disebut sebagai koefisien kinerja (coeffisient of perfomance, $C O P$ ).

$$
\text { COPaktual }=\frac{\mathrm{Qc}}{Q w} \text { atau COP }=\frac{h 2-h 3}{h 2-h 1} .
$$

\section{Heater}

Pada penelitian ini menggunakan jenis elemen pemanas listrik bentuk dasar. Dimana elemen pemanas dilapisi isolator listrik yang berbentuk keramik dan silica heater.

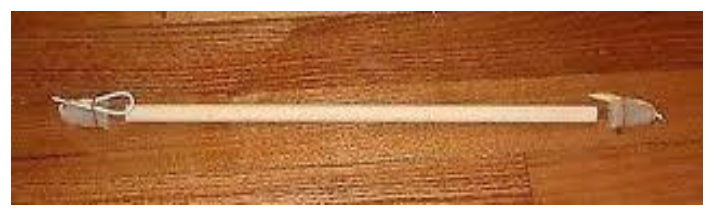

Gambar 1.5 Heater jenis elemen pemanas listrik dasar

\section{Konsep dehumidikasi}

\section{Pengertian Psikrometrik}

Psikometrik merupakan ilmu yang membahas tentang sifat-sifat campuran udara dengan uap air, dan ini mempunyai arti yang sangat penting dalam pengkondisian udara.

\section{Sifat-sifat fisik pada Psikrometrik}

Beberapa sifat yang digunakan sebagai landasan dalam penelitian adalah sebagai berikut :

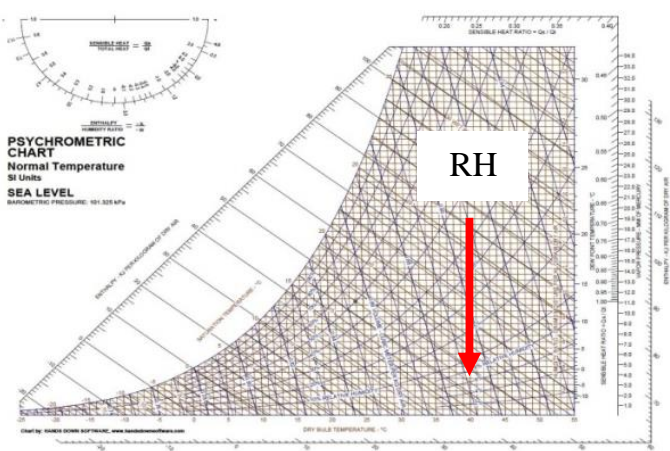

Gambar 1.6 Diagram Psikometrik proses penurunan kelembaban

1. Dry Bulb Temperatur $\left({ }^{\circ} \mathrm{C}\right)$

Suhu bola kering atau dry bulb temperatur $\left(T_{d b}\right)$ merupakan suhu campuran udara kering dan uap air yang diukur melalui skala termometer raksa secara langsung .

2. Kelembaban Relatif

Kelembaban relatif atau relative humidity $(R H)$ merupakan salah satu sifat termodinamika udara yang menyatakan perbandingan tekanan uap parsial $\left(P_{v}\right)$ terhadap tekanan uap jenuh $\left(P_{v s}\right)$, pada suhu konstan, yang hasilnya dinyatakan dalam satuan $\%$. Kelembaban relatif dapat didekati dengan persamaan :

$$
\mathbf{R H}=\mathbf{P v} / \mathbf{P v s}
$$

Dimana:

$$
\begin{array}{ll}
R H & =\text { Kelembaban relatif }(\%) \\
P_{v} & =\text { Tekanan uap parsial }(\mathrm{kPa}) \\
P_{v s} & =\text { Tekanan uap jenuh }(\mathrm{kPa})
\end{array}
$$

Proses penurunan kelembaban (dehumidifikasi) adalah proses pengurangan kandungan uap air ke udara sehingga terjadi penurunan entalpi dan ratio kelembaban. Garis proses pada karta psikometrik adalah garis vertikal ke arah bawah (Gambar 1.6).

\section{Perhitungan Beban Pemanasan}

\section{Beban Melalui Dinding}

Untuk mengetahui beban dinding dapat menggunakan rumus[7] :

Beban eksternal terdiri dari dinding, lantai, atap,dan radiasi matahari. Namun karena dalam penelitian ini room (kabin) tidak langsung terkena sinar matahari maka dapat di asumsikan tidak ada beban radiasi matahari (fenestrasi).

$$
\mathrm{Q}=\mathrm{U} \times \mathrm{A} \times \Delta T
$$

Keterangan :

$$
\begin{array}{ll}
\mathrm{Q} & =\text { Cooling load }(\text { Watt }) \\
\mathrm{U} & =\text { Overall heat transfer coefficient, }\left(\mathrm{W} / \mathrm{m}^{2} \mathrm{~K}\right) \\
\mathrm{A} & =\text { Area }(\mathrm{m} 2) \\
\Delta T & =\text { PerbedaanTemperatur }(\mathrm{K})
\end{array}
$$

\section{Beban Produk}

Untuk mengetahui beban orang dapat menggunakan rumus [7] :

$$
\mathrm{Q}_{\text {prod }} \quad=\mathrm{mxcp} \times \Delta T / \mathrm{n} .3600 \mathrm{~s}
$$

Keterangan : 
Qprod = beban produk ikan (Watt)

$\mathrm{Cp} \quad=$ panas spesifik ikan $(\mathrm{kJ} / \mathrm{kg} . \mathrm{K})$

$\Delta T=$ perbedaan temperatur $(\mathrm{K})$

$\mathrm{n} \quad=$ lama waktu pemanasan

\section{Beban Infiltrasi}

Untuk mengetahui beban infiltrasi dapat menggunakan rumus [7] :

$$
q_{t}=q D_{t} D_{f}(1-E)
$$

\section{Keterangan :}

- $\quad q_{t}$ : Beban pemanasan akibat bukaan pintu, kW

- $q$ : Beban maksimum pada aliran mantap

- $\quad D_{t}$ : Faktor waktu bukaan pintu

○ $\quad D_{f}$ : Faktor aliran akibat bukaan pintu

- E : Efektifitas alat pelindung pintu/bukaan

- Besarnya faktor waktu bukaan pintu :

○ $D_{t}=\frac{\left(P \theta p+60 \theta_{o}\right)}{3600 \theta_{d}}$

$>$ Faktor waktu bukaan pintu

$$
\text { ○ } D_{t}=\frac{\left(P \theta p+60 \theta_{o}\right)}{3600 \theta_{d}}
$$

$>$ atau faktor rapat massa

$$
\circ F_{m}=\left[\frac{2}{1+\left(\frac{\rho_{r}}{\rho_{i}}\right)^{\frac{1}{3}}}\right]^{1,5}
$$

$>$ Beban maksimum pada aliran mantap

$$
\text { ○ } \quad q t=0,221 A\left(h_{r}-h_{i}\right) \rho_{r}\left(1-\frac{\rho_{i}}{\rho_{r}}\right)^{0,5}(g H)^{0,5}\left(F_{m}\right)
$$

$>$ Beban Infiltrasi akibat bukaan pintu

$$
\text { ○ } q_{i d}=q D_{t} D_{f}(1-E)
$$

\section{Beban Alat (Heater)}

Untuk mengetahui beban heater dapat menggunakan rumus [7] :

$$
\text { Qheater }=\mathrm{qh} \times \mathrm{n}
$$

Keterangan :

$$
\begin{array}{ll}
\mathrm{Qh} & =\text { beban daya heater (watt) } \\
\mathrm{n} & =\text { jumlah heater }
\end{array}
$$

\section{Beban Total = Qdinding + Qprod + Qinfiltrasi + Qheater (Watt)

\section{METODE PENELITIAN}

Tahapan pelaksanaan penelitian yang dilakukan adalah:

1. Perencanaan

Tahapan perencanaan dalam pelaksanaan penelitian ini adalah sebagai berikut :

a. Melakukan survey / observasi dan wawancara langsung dilokasi mitra mengenai problem yang terjadi selama memanfaatkan pengering ikan alami/konvensional

b. Melakukan studi pustaka terkait dengan menentukan metode dan sistem yang tepat untuk permasalahan pengawetan ikan dalam pengeringan

c. Merancang alat pengering dengan terlebih dahulu menghitung parameter -parameter apa saja yang akan diperlukan dalam mendesain system pengering yang menggunakan metode heating dehumidifikasi yang memanfaatkan AC split dengan refrigerant ramah lingkungan, seperti parameter temperatur pengeringan, kelembaban relative( $\mathrm{RH})$, laju aliran udara, dan waktu pengeringan[4]. Perhitungan kapasitas pengeringan berdasarkan data-data rancangan dan plot diagram psikrometrik.

2. Pelaksanaan

Tahapan ini adalah proses pembuatan unit atau alat pengering dengan metode heating dehumidifier, termasuk pengujian dan pengambilan data untuk dianalisa

3. Evaluasi

Tahapan selanjutnya setelah merencanakan dan melaksanakan penelitian adalah mengevaluasi semua tahapan yang sudah dijalankan berdasarkan peubah yang ditetapkan dan menarik kesimpulan dari hasil kegiatan ini.

\section{Alur Penelitian}

Penelitian ini dilakukan melalui alur kerangka dasar yang sudah direncanakan sebelumnya dengan tahapan-tahapan alur sebagai berikut.

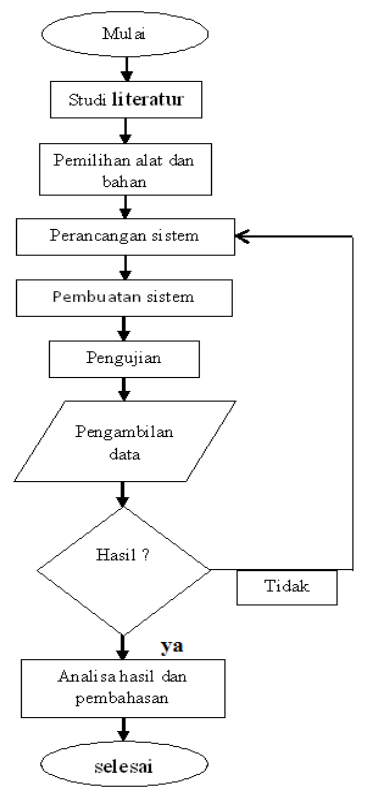

Gambar 2.1 Flowchart kegiatan Penelitian

\section{Spesifikasi Rancangan Alat}

Sebelum melakukan pembuatan alat penelitian, terlebih dahulu menentukan spesifikasi atau rancangan dari alat heating dehumidifier, dengan mempertimbangkan kemampuan kerja dari sistem kompresi uap AC Split. Spesifikasi yang diajukan, yaitu :

a. Menggunakan AC Split 1 pk dengan bahan pendingin / refrigeran R32.

b. Kabin untuk ruang sistem menggunakan bahan kayu triplek14 $\mathrm{mm}$ dan berdimensi panjang $100 \mathrm{~cm}$, lebar $87 \mathrm{~cm}$, dan tinggi $61 \mathrm{~cm}$.

c. Menggunakan heater 130 watt sebanyak 2 buah.

d. Ducting, dipergunakan sebagai saluran udara di unit AC menuju ke ruang pengering.

e. Fan/blower penghisap/tekan udara

\section{Model Rancangan Alat}




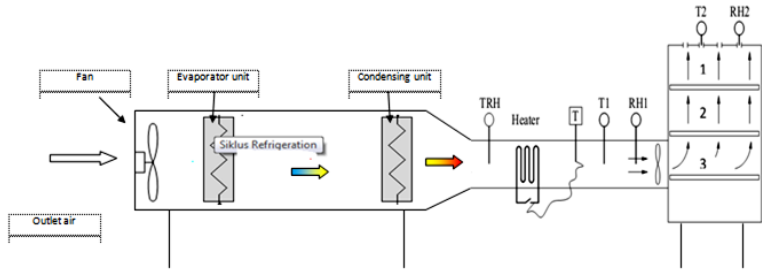

Gambar 2.2 Skema Rancangan Alat Heating Dehumidifier

Penjelasan gambar :

Alat pengering dirancang seperti skema pada Gambar 2.2 dengan 3 (tiga) bagian utama yaitu(1) system AC split yang di modifikasi menjadi system heating dehumidifier, dimana kalor udara luar diserap oleh evaporator untuk didinginkan hingga terjadi kondensasi, kemudian proses aliran udara dipanaskan melalui condensing unit untuk menurunkan kelembaban (dehumidifikasi),(2) setelah itu melalui saluran udara dengan penambahan heater untuk pemanasan (heating) dan,(3) ruang pengering yang dilengkapi dengan ventilasi udara. Saluran udara (ducting) berfungsi sebagai pembawa udara panas yang dilengkapi fan dari ruang sistem AC split menuju ruang pengering dan melewati susunan rak-rak berisi ikan,akhirnya ke luar melewati lubang-lubang ventilasi yang terdapat pada dinding atas (gambar 2.2).

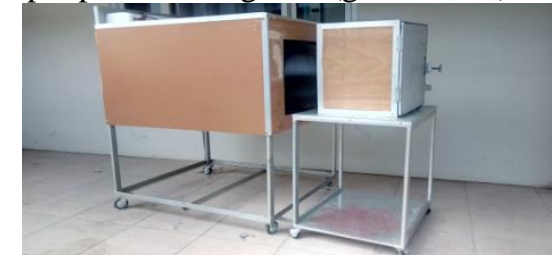

Gambar 2.3 Sistem Heating Dehumidifier

\section{Perhitungan Rancangan}

\section{Penentuan Produk}

Pada penelitian ini menggunakan ikan petek regang(Eubleekeria rapsoni) sebagai produk, Batas kadar air ikan secara umum yang diperlukan $30 \%$ sampai $40 \%$, supaya perkembangan jasad - jasad bakteri pembusuk dan jamur dapat terhenti. (Moeljanto1992). Khusus untuk pengeringan ikan, temperatur pengeringan yang dianjurkan adalah $40{ }^{\circ} \mathrm{C}-50^{\circ} \mathrm{C}$.

\section{Perhitungan Beban Pendinginan}

Berdasarkan data yang diperoleh dari rancangan dapat diperhitungkan beban pendinginan sebagai berikut :

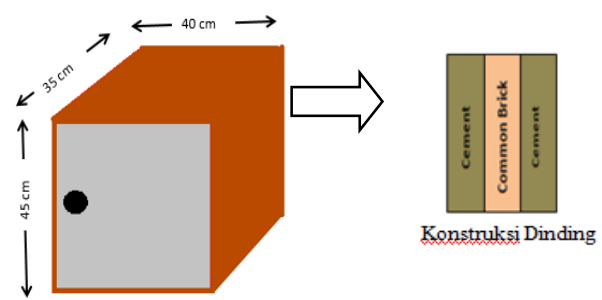

Gambar 2.4 Skema Kontruksi Rancangan pada kabin Keterangan:

- p : Panjang ( 40,5 cm )

- 1 : Lebar $(35 \mathrm{~cm})$

- $\mathrm{t}$ : Tinggi $(45 \mathrm{~cm})$
Tabel 2.1 Bahan Material Kabin

\begin{tabular}{|c|c|c|c|c|}
\hline No & Bahan & $\begin{array}{l}\text { Ketebalan } \\
\text { (m) }\end{array}$ & $\begin{array}{c}\mathrm{K} \\
(w / m \cdot k)\end{array}$ & $\begin{array}{c}\mathrm{C} \\
\left(w / m^{2} \cdot k\right)\end{array}$ \\
\hline 1 & Papan triplek & 0.015 & 0,13 & \\
\hline 2 & $\begin{array}{l}\text { Koefesiensi } \\
\text { udara } \\
\text { Permukaan luar }\end{array}$ & & & 22,7 \\
\hline 3 & $\begin{array}{l}\text { Koefesiensi } \\
\text { udara } \\
\text { Permukaan } \\
\text { dalam }\end{array}$ & & & 9,37 \\
\hline 4 & Plat seng & 0,001 & 116 & \\
\hline
\end{tabular}

Dengan menggunakan persamaan pada Beban Pemanasan dapat diperoleh total pemanasan sebagai berikut :

Beban total $=$ QKonduksi $+\mathrm{qi}+$ Qproduk Tot + Qheater $=0,13+0,121+0,0073+0,26$

$$
=0,518 \mathrm{~kW}
$$

Safety Factor $\quad=10 \% \times$ Beban $_{\text {keseluruhan }}$

$$
=10 \% \times 0,518
$$$$
=0,0518 \mathrm{~kW}
$$

BebanTotal $(\mathrm{QT}) \quad=0,518+0,0518$

$$
=0,57 \mathrm{~kW}=570,1 \text { watt }
$$

Berdasarkan perhitungan beban pemanasan pada kabin menggunakan 2 heater, didapat hasil kapasitas pemanasan sebesar 570,1 W, sehingga memungkinkan untuk menambah kapasitas produk.

\section{Perhitungan Efisiensi}

Menghitung efisiensi system heating dehumidifier tanpa heater :

Diperoleh perhitungan beban pemanasan total $(\mathrm{QT})=$ $284 \mathrm{~W}$, daya listrik masukan $(\mathrm{P})=620,4 \mathrm{~W}$

$$
\eta=\frac{Q T}{P}=\frac{\text { Beban total }}{\text { Daya input }}=\frac{Q T}{V . I}=45,8 \%
$$

Untuk efisiensi system heating dehumidifier dengan 2 heater :

Diperoleh perhitungan beban pemanasan total $(\mathrm{QT})=$ $518 \mathrm{~W}$, daya listrik masukan $(\mathrm{P})=620,4 \mathrm{~W}$

$$
\eta=\frac{Q T}{P}=\frac{\text { Beban total }}{\text { Daya input }}=\frac{Q T}{V . I}=71,3 \%
$$

Dari perhitungan efisiensi system heating dehumidifier, dapat dilihat perbandingan efisiensi antara penggunaan heater dengan tanpa heater, dimana penggunaan heater lebih tinggi nilainya dibandingkan dengan system yang tidak menggunakan heater (pemanas).

\section{HASIL DAN PEMBAHASAN}

Setelah dilakukan pengambilan data, maka data yang telah didapatkan tersebut diolah untuk mengetahui hasil dari sistem yang telah dirancang.

Perhitungan COP (Coefisien Of Performance) dari Sistem Kompresi Uap

Tempout kondensor $=50$

Tempout evaporator $=25$

Data rancangan dengan menggunakan diagram p-h:

Kerja kompresi adalah :

$\begin{aligned} \mathrm{q}_{\mathrm{w}} & =\mathrm{h}_{2}-\mathrm{h}_{1}=546,2 \mathrm{~kJ} / \mathrm{kg}-517,8 \mathrm{~kJ} / \mathrm{kg} \\ & =28,4 \mathrm{~kJ} / \mathrm{kg}\end{aligned}$ 
Kalor yang dibuang oleh kondensor adalah :

$\mathrm{q}_{\mathrm{c}} \quad=\mathrm{h}_{2}-\mathrm{h}_{3}=546,2 \mathrm{~kJ} / \mathrm{kg}-299,5 \mathrm{~kJ} / \mathrm{kg}$ $=246,7 \mathrm{~kJ} / \mathrm{kg}$

Maka nilai COP untuk sistem dapat diketahui :

$$
\mathrm{COP}=\mathrm{q}_{\mathrm{c}} / \mathrm{q}_{\mathrm{w}} \quad=8,6
$$

Tanpa heater

Temp out kondensor $=42,8$

Temp out evaporator $=29,9$

Dengan menggunakan diagram $\mathrm{p}-\mathrm{h}$ diperoleh:

Kerja kompresi adalah :

$$
\begin{aligned}
\mathrm{q}_{\mathrm{w}} & =\mathrm{h}_{2}-\mathrm{h}_{1}=545,2-515,4 \\
& =29,8 \mathrm{~kJ} / \mathrm{kg}
\end{aligned}
$$

Kalor yang dibuang oleh kondensor adalah :

$$
\mathrm{q}_{\mathrm{c}} \quad=\mathrm{h}_{2}-\mathrm{h}_{3}=545,2-280,1
$$

$$
=265,1 \mathrm{~kJ} / \mathrm{kg}
$$

Maka nilai COP untuk sistem dapat diketahui :

$$
\mathrm{COP}=\mathrm{q}_{\mathrm{c}} / \mathrm{q}_{\mathrm{w}} \quad=8,89
$$

Dari perhitungan COP antara data rancangan dengan data hasil pengujian tidak terjadi perbedaan yang signifikan. Untuk meningkatkan performansi pemanasan sesuai yang diinginkan dilakukan dengan penambahan heater dengan daya $130 \mathrm{~W}$.

\section{Menggunakan Heater 130 W}

Temp out kondensor $=41,5$

Temp out evaporator $=28$

Dengan menggunakan diagram $\mathrm{p}$-h diperoleh:

Kerja kompresi adalah :

$$
\begin{aligned}
\mathrm{q}_{\mathrm{w}} & =\mathrm{h}_{2}-\mathrm{h}_{1}=541,5 \mathrm{~kJ} / \mathrm{kg}-515 \mathrm{~kJ} / \mathrm{kg} \\
& =26,5 \mathrm{~kJ} / \mathrm{kg}
\end{aligned}
$$

Kalor yang dibuang oleh kondensor adalah :

$$
\mathrm{q}_{\mathrm{c}}=\mathrm{h}_{2}-\mathrm{h}_{3}=541,5 \mathrm{~kJ} / \mathrm{kg}-280,9 \mathrm{~kJ} / \mathrm{kg}
$$$$
=260,6 \mathrm{~kJ} / \mathrm{kg}
$$

Maka nilai COP untuk sistem dapat diketahui :

$$
\mathrm{COP}=\mathrm{q}_{\mathrm{c}} / \mathrm{q}_{\mathrm{w}} \quad=9,8
$$

Setelah penambahan heater, dapat diperoleh kenaikan performansi (COP) sebesar 9,8

Plot Diagram Psicrometrik Pada Penggunaan Produk Analisa diagram psikrometrik membandingkan antara produk yang menambahkan heater dan tanpa heater, dimana dilakukan dalam 3(tiga) tahapan. Setiap tahapan dilakukan dengan memvariasikan temperatur dengan nilai $40^{\circ} \mathrm{C}, 45^{\circ} \mathrm{C}, 50^{\circ} \mathrm{C}$.

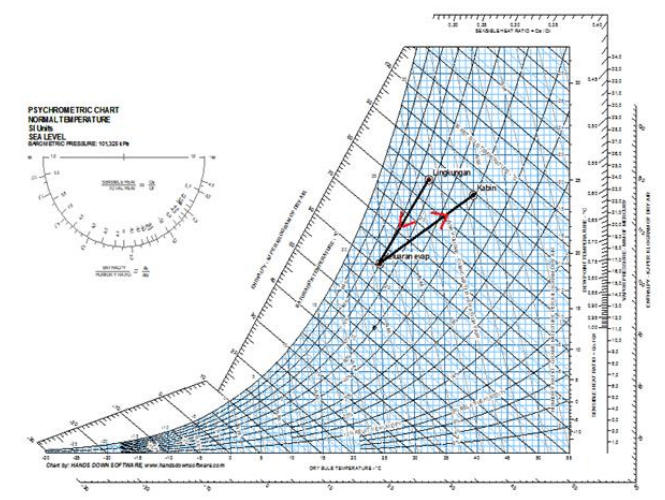

Gambar 3.4 Diagram Psikrometrik dengan setting temperatur Heater $50{ }^{\circ} \mathrm{C}$ (yang mendekati rancangan)

Dari 4 variabel pengujian di atas, disimpulkan temperatur dan kelembaban relatif yang mendekati data yang dipersyaratkan untuk pengeringan adalah settingan $50^{\circ} \mathrm{C}$ garis warna biru (settingan temperatur heater $50{ }^{\circ} \mathrm{C}$ )yang memiliki nilai kelembaban $32,1 \%$.

\section{PENUTUP}

\section{Kesimpulan}

Berdasarkan hasil pengujian dan analisa pembahasan, dapat disimpulkan performansi system heating dehumidifier yang menambahkan heater memiliki efisiensi tinggi dibandingkan tanpa menggunakan heater, yaitu sebesar $71 \%$. Begitu pula dengan COP dari system kompresi uap pada AC split yang menambahkan heater lebih tinggi nilainya sebesar 9,8. Untuk hasil plot diagram psikrometrik perbandingan temperatur dan kelembaban relatif $(\mathrm{RH})$ yang mendekati data yang dipersyaratkan adalah pada settingan temperatur heater $50{ }^{\circ} \mathrm{C}$, dimana diperoleh nilai temperatur output $50{ }^{\circ} \mathrm{C}$, dan RH sebesar $32,1 \%$.

\section{Saran}

1. Dalam pengambilan data pengujian, sebaikanya perlu dilengkapi dengan control system temperatur dan kelembaban, dan kecepatan aliran udara agar diperoleh data yang stabil.

2. Disamping itu pengambilan data jarak interval pengukuran tidak terlalu jauh, sehingga hasilnya lebih akurat;

\section{DAFTAR PUSTAKA}

[1] Fadhil, Rahmat.2005, Pengeringan, Jurusan Teknik Pertanian, Darusalam Banda Aceh.

[2] Handoyo, Ekadewi A; Philip Kristanto; Suryanty Alwi, 2011, Desain dan Pengujian Sistem Pengering Ikan Bertenaga Surya, Jurusan Teknik Mesin Fakultas Teknologi Industri Universitas Kristen Petra, Surabaya

[3] Setyoko, Bambang; Senen, Seno Darmanto. 2008, Pengering Ikan Teri dengan Vakum dan Paksa, Majalah Info Edisi XI, No. 1, Pebruari 2008

[4] Abdullah, Kamaruddin,2003, "Fish Drying Using Solar Energy" Lectures and Workshop Exercises on Drying of Agricultural and Marine Products: Regional Workshops on Drying Technology, Jakarta, 159-191. [5] Astrain et al, 2005, "Computational model for refrigerators based on Peltier effect application", Jurnal Applied Thermal Engineering vol 25 page 3149-3162

[5] http://archive.constantcontact.com/

[6] http://www.humiditycontrol.co.uk/dehumidificationtheory.html

[7] Dossat, Roy J. 1981.Principles of Refrigeration.Second Edition. SI Version. New York. John Wiley \& Sons, Inc. USA.

[8] Lamatta, A.R. 2012. Identifikasi Ikan Yang Didaratkan di PPN PelabuahanRatu, Edisi 1. Ditjen Tangkap KKP - Pelabuhan Perikanan Nusantara Pelabuhanratu 